\title{
IMPACTS OF LOAN-TO-VALUE CEILINGS IN THE BRAZILIAN MORTGAGE LOANS
}

\author{
Nadiejda Sá * \\ Ana Carolina Zoghbi ${ }^{\dagger}$ \\ RAFAEL TERRA $\ddagger$
}

\begin{abstract}
This study aims to assess the impact of loan-to-value ceiling applied by Resolution BCB No. 4,271 on the mortgage market in September 2013. Based on public aggregated data, we assessed the effect of the regulatory change on the loan-to-value and on quality of the portfolio using impact evaluation techniques that aim to estimate true causal effects. Results suggest the intervention did not reduce total mortgage loans. Interrupted time series and differences-in-differences estimates show statistically significant effects on the quality of the portfolio measured by the proportion of poorly rated credits.
\end{abstract}

Keywords: loan-to-value ratio on the loan amount, real estate loans, differencein-differences, interrupted time series, synthetic control.

\section{Resumo}

O objetivo do presente estudo é avaliar o impacto do teto do valor do empréstimo aplicado pela Resolução BCB 4.271 no mercado de hipotecas em setembro de 2013. Com base em dados públicos agregados, avaliamos o efeito da mudança regulatória no valor dos empréstimos e na qualidade do portfólio usando técnicas de avaliação de impacto que buscam estimar verdadeiros efeitos causais. Os resultados sugerem que a intervenção não reduziu o total de empréstimos hipotecários. As estimativas de séries temporais interrompidas e diferenças em diferenças mostram efeitos estatisticamente significativos na qualidade da carteira, medida pela proporção de créditos com classificação ruim.

Palavras-chave: tetos de empréstimos sobre valor financiado, empréstimo imobiliário, diferenças-em-diferenças, série temporal interrompida, controle sintético.

JEL classification: F38, G21, G28, O16.

DOI: ht tp://dx.doi .org/10.11606/1980-5330/ea 153614

\footnotetext{
* Banco Central do Brasil. E-mail: deanesa@yahoo.com

† Universidade de Brasília (UnB). E-mail: acpzoghbi@unb.br

‡ Universidade de Brasília (UnB). E-mail: rterra@unb.br
} 


\section{Introduction}

This study aims to evaluate the effects of Resolution 4,271 from September 2013 enacted by Central Bank - of Brazil - which established the loan-to-value ceiling on mortgages on total mortgage and quality of the portfolio. We use public and aggregated data and adopt proper impact evaluation techniques to estimate the causal effect of the intervention.

The housing bubble of 2008 strongly affected the housing market and rapidly spread to different market segments, becoming a global financial crisis. Since then, several policies were suggested to reduce vulnerabilities of the financial system. On the housing market, the relationship between property taxes and house prices is well documented. Thus property taxes are often pointed as an effective policy to inhibit speculation and decrease prices (Bai et al. 2014). On the financial markets, central banks, supervisory agencies and multilateral organizations have also identified the need to improve the agents regulation to avoid new crises and attenuate their impacts. Conventional supervision, focusing on individual financial institutions revealed insufficient to maintain the financial system stability. Macroprudential regulation, focused on systemic risk and aimed at promoting economic and financial stability, has become necessary to complement microprudential regulation ${ }^{1}$.

The real estate sector has received special attention by prudential regulators because of its expansion and retraction cycles on the Brazilian real economy and financial system. Crowe et al. (2011) argue that the expansion cycle of the real estate market may not affect macroeconomic stability, but how such an expansion takes place does. The expansion financed by the excessive leverage of financial institutions have negative effects because, at the end of the cycle, the impact of reduced real estate prices on the economy is amplified by the financial effects from the deleveraging of lenders following the default by borrowers.

Macroprudential policies control real estate booms and preserve quality of credit portfolios. Reserve requirements, interbank exposure limits, loan-tovalue (LTV) and debt service-to-income (DTI) ratio ceiling imposition stands out among the most used tools to implement these policies. Gete \& Reher (2016) argue that LTV limits can reduce cost to lenders, but also reduce benefits of potential homeowners. The authors propose a mortgage market model with LTV limits in which heterogeneous households can choose to rent or buy real estate. Buying is only possible with mortgage loans. Mortgages can be recourse or nonrecourse loans. Lenders must break even, and optimal LTV must balance benefits of homeownership and costs and externalities of defaulting real estate mortgages. Optimal LTV produced in this model can help policymakers to better tailor ceiling limits and reach more efficient results.

Kuttner \& Shim (2016), based on data from 57 countries over three decades, investigate the effect of LTV adoption on prices in the housing market, finding no significant effects of such policy. Wong et al. (2011), in turn, use a panel of countries to evaluate the impacts of LTV ceiling imposition and conclude that the adoption of this policy reduced the sensitivity of default risks to price shocks. Thus, the policy was effective in reducing the systemic risk

\footnotetext{
${ }^{1}$ Systemic risk is understood here as the probability of disruption in financial services when the system is subjected to shocks despite meeting microprudential requirements (Silva et al. 2012).
} 
arising from housing market expansion and contraction cycles. However, it had insignificant effect on the increase of real estate prices in the short term.

Lim et al. (2011) rely on a sample of 49 countries to evaluate the effect of macroprudential policies and conclude that over $50 \%$ of countries reduced credit growth and asset prices after enacting LTV ceilings. Regression analysis suggest the limits on LTV and DTI reduce the procyclicality of credit instruments. Claessens et al. (2013) assess the effect of LTV and DTI ceilings adoption on the balance sheets of 2,800 banks in 48 different countries and conclude that the limits are effective in reducing the growth and leverage of bank assets.

Morgan et al. (2018) analyze the effect of LTV changes on mortgage loans. The authors use data of over 4,000 banks in 46 countries. This dataset makes the study stand out from the others. The authors look at the effects of adopting LTV, captured by the inclusion of a dummy for the ceiling adoption. The results show a reduction of $5.9 \%$ in mortgage loans after LTV.

Two recent studies conducted in Brazil have evaluated the effect of macroprudential policies involving LTV regulation. Afanasieff et al. (2015) evaluated the effect of the regulatory change implemented in December 2010 that increased the risk associated with automobile credit operations with high LTV and long maturities. Results suggest reduced default rates and total credit amount confirming the expectations. Araujo et al. (2017) study the effects of a LTV ceiling imposition to the real estate market on the behavior of borrowers using different datasets and estimation strategies. They conclude that the imposition of more conservative ceilings to the credit regulated segment reduce both the payment delays and the mean value of loans.

Li \& Yavas (2017) recommend LTV to be set individually. They argue that the importance of the land value share on total property value has been neglected as an important determinant of the default risk on mortgage markets. According to the authors, the volatility of property prices results mostly from the higher volatility of land prices. Testing test the effect of the land price share to total property price on the risk of mortgage default, results show that the higher the land price share to total property value, the higher the default probability. Thus, the authors recommend that LTV should consider the land value share to total property value of each mortgage loan applicant and that it should be set individually.

The contributions of this paper to the literature are threefold. First, we evaluate the application of an LTV ceiling and its effects on volume and quality of credit in a developing country facing rapid mortgage loans growth. We use both country-level information to evaluate the effects of LTV on total loans, and local level credit information that allows comparing mortgage loans of regulated and non-regulated sectors to assess impacts on the quality of credit portfolio. In Brazil, the mortgage loans offered by private banks are, for the most part, not subject to the Housing Financing System (SFH - Sistema de Financiamento Habitacional) rules, public banks, in turn, are restricted by the LTV limits on Resolution 4,271 from 2013. Second, since each country adopts different LTV limits, to collect as much evidence as possible on the countries' experiences is important. Third, we rely on impact evaluation strategies that seek estimates of the true causal effect of the macroprudential intervention.

To estimate the effect of the LTV intervention on the volume of credit we use Synthetic Control methodology, with which we compared the Brazilian 
case study to various countries that did not adopt LTV ceilings during the period. The results indicate that the credit did not decrease in response to LTV, which might be good if accompanied by credit portfolio quality improvement.

In this sense, exploratory analysis using interrupted time series (ITS) suggests an increase in the quality of the credit portfolio on aggregate. Analysis with difference-in-differences (DID) confirms the result with more disaggregated data. We use local level mortgage loans data for regulated and nonregulated credit and find evidence that the quality of mortgage portfolio increased among regulated sector, which were subject to the SFH rules and LTV limits. A robustness test of previous parallel trends reinforce the causality of the result.

This paper is divided into four sections in addition to this introduction. Section 2 addresses the Institutional Framework, the rapid growth observed in recent years and recent institutional changes. Section 3 describes the effects of the LTV intervention on total mortgage loans. Section 4 describes the effects on the quality of the portfolio. Section 5 concludes.

\section{Institutional Framework}

After the debt crisis in the early 1980s, the Brazilian economy experienced a period of strong macroeconomic instability and hyperinflation that worsened the quality of the mortgage portfolio and led to the SFH crisis. Even after the stabilization of the economy in the second half of the 1990s, which began with the adoption of Plano Real in 1994, the recovery of real estate loans remained inexpressive. The mortgage loans expansion only gained traction in the last decade, particularly between 2009 and 2014.

The strong expansion in mortgage lending verified in Brazil during the last decade is a result of favorable terms of trade, sustained growth, sound fundamentals, legal reforms and facilitated financing conditions. The volume of loans increased from 48.4 billion reais in December 2004 to 502.9 billion reais in December $2014^{2}$.

Two institutional changes that increased mortgage loans stand out: the improvement of legislation on patrimony of affectation and fiduciary alienation ${ }^{3}$ - which increased security to borrowers and lenders, and the renegotiation of the housing debt of the Wage Variation Compensation Fund (FCVS), which freed public resources to be channeled to mortgage market.

The housing program denominated Minha Casa, Minha Vida (MCMV My House, My Life, in Portuguese), launched after the 2008 crisis, was also important for the credit growth. It aimed to reduce the housing deficit by strengthening the participation of public banks. Figures 1 and 2 show the rapid housing credit growth and how significant MCMV was in such an expansion. ${ }^{4}$.

\footnotetext{
${ }^{2}$ Information retrieved from Central Bank Credit Information System (SCR). Prices are adjusted to values of June 2017.

${ }^{3}$ See Law 10,931 from August 2004, which sets guidelines for both taxation of patrimony of affectation and fiduciary alienation.

${ }^{4}$ The program was made official by Law 11,977 on July 7th, 2009. Further information on the MCMV Program can be found at http: / / www.cidades.gov.br/habitacao-cidades/ progrmas-e-acoes-snh/67-snh-secretaria-nacional/programas-e-acoes/ 1297-programa-minha-casa-minha-vida.
} 
Figure 1: Mortgage loans by financial institutions (in billion reais)

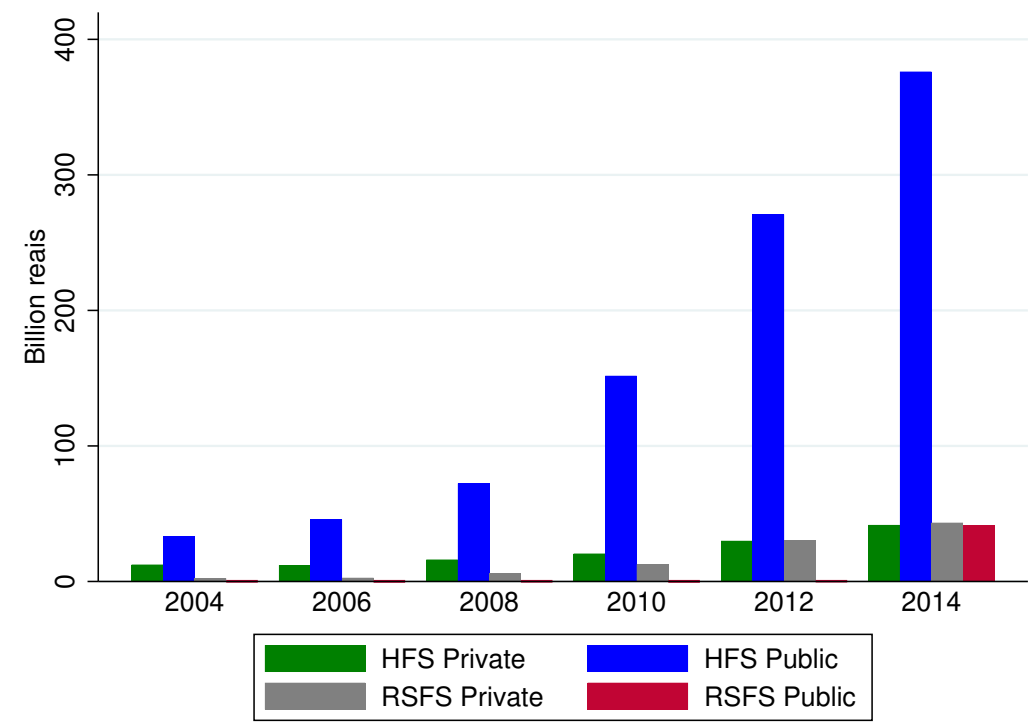

Notes: The figure shows the evolution of the mortgage portfolio. Credits are classified based on the ownership status of the financial institution - public or private - and on operation type - at market rates or regulated rates. The portfolio of operations contracted at market rates is denominated Real Estate Financing System (SFI Sistema de Financiamento Imobiliário) and the portfolio of operations contracted at regulated rates is denominated Housing Financing System (SFH). The volume of the portfolio is denominated in reais of June 2017.

Low-income families, with incomes up to 1,800 reais participated in level 1 of MCMV. Rather than loans granted by financial institutions, this level receives subsidies. Resources from the Brazilian Severance Indemnity Fund (FGTS Fundo de Garantia por Tempo de Serviço, in Portuguese) allowed expanding the loans offered by MCMV at differentiated mortgage rates and payment conditions focusing on middle-class families - with income between 4,000 and 7,000 reais - eligible for the program levels 2 and 3. Later in 2016, level 1.5 was created to attend families with incomes between 1,800 and 2,600 reais.

Mortgage loans grew rapidly in several countries of Latin America, with Brazil standing out for presenting the highest housing credit growth rates (Regional Economic Outlook Analytical Notes 2012). Experts, then, started to question the soundness of the housing credit market and vulnerabilities that could spread to the financial system and to the real economy (Otto 2015) ${ }^{5}$.

\subsection{Housing Financing Resources in Brazil}

The Brazilian housing financing system operates with two large complementary branches, i.e., the Housing Financing System (SFH) and the Real Estate Financing System (SFI). SFH was launched by Law 4,380 from August 1964, which aimed at reducing the housing deficit and at enabling a self-sustaining

\footnotetext{
${ }^{5}$ Even though default indicators such as the percentage of late payments longer than 90 days presented historically-low levels.
} 
Figure 2: MCMV - Accumulated Contracted Value - Levels 2 and 3 (in billion reais)

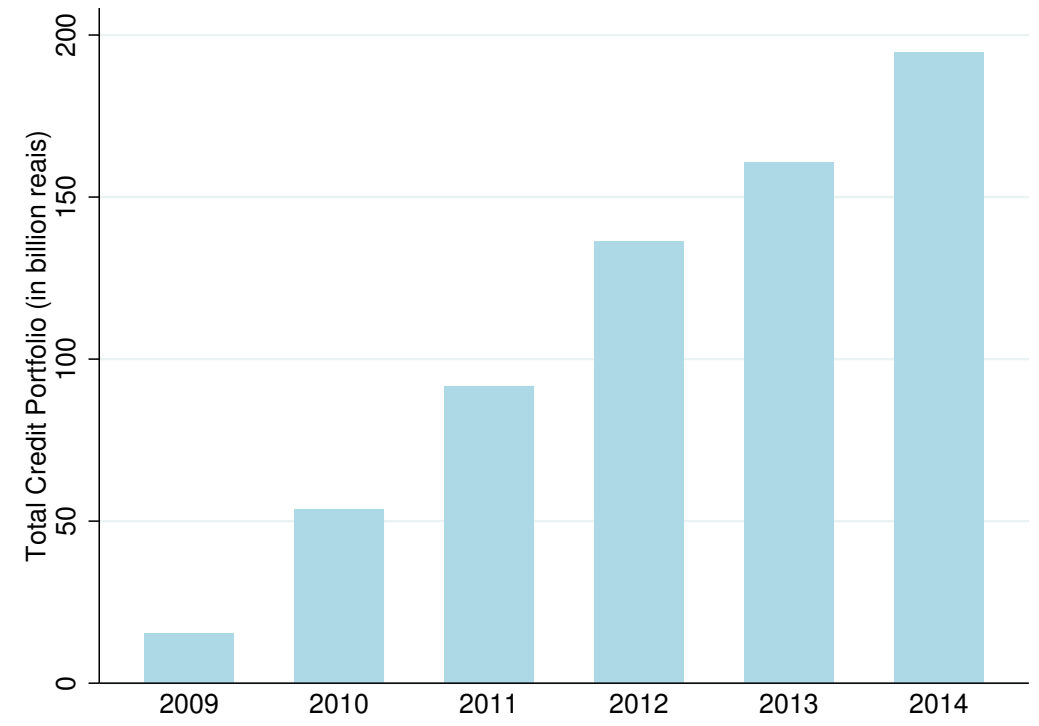

Notes: Figure shows the amount of credit offered by MCMV program levels 2 and 3. The volume of credit is denominated in reais of June 2017.

Source: Brazilian Ministry of Cities.

fund raising and investment dynamics in the housing sector. On the other hand, SFI was launched by Law 9,514 from November 1997, and aimed at enabling real estate financing processes using market mechanisms.

$\mathrm{SFH}$ is characterized by regulating financing conditions such as interest rates, maximum values for financed properties, maximum term and insurance terms conditions, as established by the National Monetary Council. A major share of SFH resources comes from the FGTS ${ }^{6}$ and the Brazilian Savings and Loans System (SBPE Sistema Brasileiro de Poupança e Empréstimos, in Portuguese).

Resources resources from both FGTS and SBPE have compulsory origin. The first consists of employer contributions, which aimed at protecting workers in case they were fired and at providing funds for housing and sanitation. SBPE funds consists of a compulsory share of total savings captured by SBPE entities ${ }^{7}$.

Recently, mortgage loans funding have changed, increasing participation of FGTS and market sources. Nonetheless, resources from targeted savings account for more than $50 \%$ of total resources ${ }^{8}$.

Finally, despite the rapid credit growth observed in recent years, the Mortgage Loans/GDP ratio (8,5\% in 2015, according to Financial Soundness Indicators (FSI)/FMI) remains low at international levels, even in comparison to

\footnotetext{
${ }^{6}$ FGTS was established by Law 5,107 from September 1966

${ }^{7}$ According to Resolution 3,932 from December, 2010, 65\% of the resources captured from saving deposits by SBPE members should be directed to housing financing. At least $80 \%$ of these $65 \%$ should be allocated to SFH operations, whereas the remainder should be allocated to operations at market rates.

${ }^{8}$ For further details on the recent diversification in funding sources, see Otto (2015).
} 
other developing countries. The high concentration of mortgage loans in few banks, and two public banks in particular is another feature of the Brazilian mortgage market, as Figure 1 shows the strong dependence of the housing loans segment on public banks and regulated rates operation types.

\subsection{Regulatory Change: Resolution 4,271 from 2013}

Resolution 4,271 from September 2013 imposed a limit on the amount to be borrowed from SFH as a share of the real estate value. Before that Resolution, Brazil LTV was unlimited, and only the amount to be borrowed was limited (see Table 1). This measure was taken in a context in which many countries were adopting such LTV ceiling policies as macroprudential tools to increase banks resilience in economic downturns.

Table 1: Pre and post-reform LTV and loan limits

\begin{tabular}{|c|c|c|c|c|}
\hline & \multicolumn{2}{|c|}{ Pre reform } & \multicolumn{2}{|c|}{ Post Reform } \\
\hline & $\begin{array}{l}2006 \text { to } \\
2009(a)\end{array}$ & $\begin{array}{c}2009 \text { to } \\
2013(b)\end{array}$ & $\begin{array}{l}2013 \text { to } \\
2018(\mathrm{c})\end{array}$ & $\begin{array}{l}2018 \text { to } \\
\text { date }(\mathrm{d})\end{array}$ \\
\hline LTV & $\begin{array}{l}\text { none (only } \\
\text { a cap on to- } \\
\text { tal loan of } \\
R \$ 245,000.00)\end{array}$ & $\begin{array}{l}\text { none (only } \\
\text { a cap on to- } \\
\text { tal loan of } \\
R \$ 450,000.00)\end{array}$ & $\begin{array}{l}80 \% \text { of the } \\
\text { property value } \\
90 \% \text { of the } \\
\text { property value } \\
\text { in CAS system }\end{array}$ & $\begin{array}{l}80 \% \text { of the } \\
\text { property value } \\
\text { in PRICE } \\
\text { system }\end{array}$ \\
\hline $\begin{array}{l}\text { Maximum } \\
\text { property } \\
\text { value }\end{array}$ & $\mathrm{R} \$ 350,000.00$ & $\mathrm{R} \$ 500,000.00$ & $\begin{array}{l}\text { R } \$ 650,000.00 \\
\mathrm{R} \$ 750,000.00 \\
\text { for the states } \\
\text { of São Paulo, } \\
\text { Rio de Janeiro, } \\
\text { Minas Gerais } \\
\text { and Distrito } \\
\text { Federal }\end{array}$ & $\mathrm{R} \$ 1,500,000.00$ \\
\hline
\end{tabular}

Notes: (a) Based on Central Bank of Brazil Resolution 3,347, from February $8^{\text {th }}$, 2006. (b)

Based on Central Bank of Brazil Resolution 3,706, from March $27^{\text {th }}, 2009$. (c) Based on

Central Bank of Brazil Resolution 4,271 from of September 30 ${ }^{\text {th }}$, 2013. (d)Based on

Central Bank of Brazil Resolution 4,676, of July 31th of 2018.

The idea behind the measure is that the greater the proportion of borrower's contribution from their own funds, the less incentive they must default if the economic conditions worsen and/or house prices negatively change. The LTV ceiling imposed by the resolution is restricted to operations contracted in compliance with SFH rules, i.e., to new loans contracted at regulated rates. The regulation is less rigorous in operations contracted with Constant Amortization System (CAS) with a limit of 90\%, in which installments decrease in time and amortization is faster. Operations contracted with the Amortization Schedule are more vulnerable to default in a property price decline scenario, so it is subject to the more conservative maximum LTV of $80 \%$. The resolution also update the maximum acceptable real estate value to be financed within the SFH. The maximum value increased from 500,000 to 750,000 reais in the country's richest states; and to 650,000 reais in other federative units (see Table 1).

The impossibility of separating the effect of the imposition of LTV limits from the limits update implies that the impact evaluation analyzed with ag- 
gregate data refers to the resolution.

\section{Total Mortgage Loans after LTV: comparisonan International Comparison}

This section presents the macroeconomic effect of the LTV intervention in September 2013 on the total amount of mortgage loans, taking a group of countries as potential counterfactuals for Brazil. Using Synthetic Control methodology allows the analysis of a homogeneous treatment, different from using groups of countries with several and potentially different interventions different LTV limits, and other confounding treatments adopted together with LTV in each country. The methodology also permits to working with aggregate data. It is often better to work with data as disaggregated as possible, within the same country; but in this case, as far as the credit volume is concerned, the imposition of LTV limits on regulated SFH credit can influence non-regulated SFI credit. Working with aggregate data avoids effects of problems repercussion between regulated and non-regulated credit.

Developed by Abadie \& Gardeazabal (2003) and Abadie et al. (2010) the Synthetic Control (SC) methodology consists in estimating the counterfactual as a linear combination of the outcomes of untreated units similar to the treated unit (See details in Appendix A).

$$
\hat{\alpha}_{1 t}=Y_{i t}^{I}-\sum w_{j}^{*} Y_{j t}^{J}{ }_{j=1}, \quad t>T_{0}, \quad i \neq j
$$

where $Y_{i t}^{I}$ is the treated unit outcome, $Y_{j t}$ are the outcomes of potential control (donor) units and weights, $w_{j}^{*}$ are set to minimize the differences between preintervention characteristics $\left(X_{i}\right)$ of treatment and control units.

We built a panel of 29 countries and 32 periods based on quarterly data between the first quarter of 2007 and the last quarter of 2014 to enable the application of the Synthetic Control methodology. The unavailability of longer series for some countries is a limiting factor to the data collection prior to 2007. In addition, data after 2015 are excluded from the study to avoid confounders, such as housing credit policies implemented by the major real estate credit provider in Brazil, Caixa Econômica Federal, in 2015.

Potential controls are selected based on studies by Martins et al. (2011) and Cerutti et al. (2015). The donor pool was selected among countries that, according to the study, did not implement macroprudential maximum LTV policies. Data are collected from Central Banks, IMF (International Financial Statistics/IFS and World Economic Outlook/WEO), World Bank (World Development Indicators), United Nations (UN) and from the European Mortgage Federation (EMF). Variables are described in Table 2.

Synthetic Control uses weights that produce a convex combination of countries that resembles Brazil the most (the synthetic Brazil). This resemblance is defined in terms of a set of covariates $X$ described in Table 2. $X$ includes the following set of macroeconomic variables ${ }^{9}$ : GDP growth (GDPVAR), GDP per capita seasonally adjusted (GDP), International USD Reserves (RESERV), Price Index (PI), Unemployment rate (UNEMPL), Quarterly GDP (quarterly GDP), Private Consumption seasonally adjusted (Consumption), Real estate

\footnotetext{
${ }^{9}$ The set of variables is similar to that used by Cerutti et al. (2015)
} 
Table 2: Definition of variables and sources

\begin{tabular}{|c|c|c|c|}
\hline & Variable & Source & Unit \\
\hline Balances & $\begin{array}{l}\text { Mortgage loans } \\
\text { balances in USD }\end{array}$ & $\begin{array}{l}\text { European Mort- } \\
\text { gage Federation } \\
\text { (EMF) } \\
\text { FSI/IMF } \\
\text { Central Banks }\end{array}$ & Millions of USD \\
\hline PIMOV & $\begin{array}{l}\text { Real estate } \\
\text { prices }\end{array}$ & 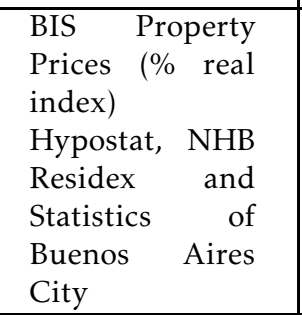 & $\begin{array}{l}\text { Index, } \\
2010=100\end{array}$ \\
\hline HDI & $\begin{array}{l}\text { Human Devel- } \\
\text { opment Index }\end{array}$ & UN & \\
\hline Pop & Population level & $\begin{array}{l}\text { IMF } \\
\text { World Economic } \\
\text { Outlook (WEO) }\end{array}$ & $\begin{array}{l}\text { Millions of peo- } \\
\text { ple }\end{array}$ \\
\hline GDP & $\begin{array}{l}\text { GPD per capita } \\
\text { - seasonally ad- } \\
\text { justed }\end{array}$ & $\begin{array}{l}\text { World Bank } \\
\text { World Develop- } \\
\text { ment Indicators }\end{array}$ & $\begin{array}{l}\text { constant } 2010 \\
\text { USD }\end{array}$ \\
\hline RESERV & $\begin{array}{l}\text { International } \\
\text { Reserves in USD } \\
-\quad \text { seasonally } \\
\text { adjusted } \\
\end{array}$ & $\begin{array}{l}\text { International } \\
\text { Financial Statis- } \\
\text { tics (IFS) }\end{array}$ & Millions of USD \\
\hline GDPVAR & GDP variation & $\begin{array}{l}\text { International } \\
\text { Financial Statis- } \\
\text { tics (IFS) }\end{array}$ & \\
\hline PI & Price Index & $\begin{array}{l}\text { Source: Interna- } \\
\text { tional Financial } \\
\text { Statistics (IFS) }\end{array}$ & \\
\hline UNEMPL & $\begin{array}{l}\text { Unemployment } \\
\text { - seasonally } \\
\text { adjusted }\end{array}$ & $\begin{array}{l}\text { International } \\
\text { Financial Statis- } \\
\text { tics (IFS) }\end{array}$ & $\%$ \\
\hline GDP quarterly & $\begin{array}{l}\text { Quarterly GDP } \\
\text { in National Cur- } \\
\text { rency - season- } \\
\text { ally adjusted }\end{array}$ & $\begin{array}{l}\text { FMI/International } \\
\text { Financial Statis- } \\
\text { tics (IFS) }\end{array}$ & $\begin{array}{l}\text { Millions in Na- } \\
\text { tional Currency }\end{array}$ \\
\hline \multirow[t]{2}{*}{ Consumtion } & \multirow[t]{2}{*}{$\begin{array}{lr}\text { Private } & \text { con- } \\
\text { sumption } & - \\
\text { seasonally } & \\
\text { adjusted } & \end{array}$} & $\begin{array}{l}\text { FMI/ Interna- } \\
\text { tional Financial } \\
\text { Statistics (IFS) }\end{array}$ & $\begin{array}{l}\text { Millions in } \mathrm{Na}- \\
\text { tional Currency }\end{array}$ \\
\hline & & $\begin{array}{l}\text { FED St } \\
\text { Louis/Central } \\
\text { Banks }\end{array}$ & \\
\hline Credit & $\begin{array}{l}\text { Credit to the Pri- } \\
\text { vate Sector }\end{array}$ & $\begin{array}{l}\text { BIS } \\
\text { Central Banks }\end{array}$ & $\begin{array}{l}\text { Millions in Na- } \\
\text { tional Currency }\end{array}$ \\
\hline
\end{tabular}


prices (PIMOV), Credit to the private sector except real estate loans (Credit), Human Development Index (HDI), and Population (Pop). That procedure is analogous to controlling for the same variables, with the advantage that it does not assume linear relationship between control variables, LTV and mortgage loans. These variables are associated with the development of the credit market as well as with the economy activity level.

We built a synthetic Brazil as a convex combination of countries in the donor pool ${ }^{10}$. The characteristics of the nine selected predictors and lagged dependent variables are very similar between Brazil and its synthetic counterpart. The countries that compose synthetic Brazil are Australia, France, India, Peru and Russia, with more weight given to the last one (see weights in Table B.1). To order to evaluate the fit between synthetic and treated units in the pre-treatment period, Abadie et al. (2014) suggest calculating the root mean square prediction error (RMSPE) based on the outcome deviations from its synthetic counterpart.

$$
\text { RMSPE }=\sqrt{\frac{1}{T_{0}} \sum_{1}^{T_{0}}\left(Y_{i t}-\sum_{j=1}^{J} w_{j}^{*} Y_{j t}\right)}
$$

Adhikari \& Alm (2016) suggested calculating the "Fit index" by normalizing the RMSPE to make the interpretation easier. Accordingly, the RMSPE of a zero-fit benchmark is calculated as

$$
R M S P E_{\text {benchmark }}=\sqrt{\frac{1}{T_{0}} \sum_{1}^{T_{0}}\left(Y_{i t}\right)^{2}}
$$

and the index is obtained by taking the RMSPE proposed by Abadie et al. (2014).

$$
F I T=\frac{R M S P E}{R M S P E_{\text {benchmark }}}
$$

The closer to one the index, the worst the predictive power of the model. On the other hand, the closer to zero, the better the fit. Table 3 presents the RMSPE and the Fit Index of different pre-treatment periods. The indexes suggest an appropriate fit for the 2010-2013 period.

Table 3: Model adjustment in the Pre-treatment Period for control units: RMSPE and Fit index

\begin{tabular}{l|c|c|c}
\hline & 2010Q1-2013Q3 & 2011Q1-2013Q3 & 2012Q1-2013Q3 \\
\hline RMSPE & 0.15 & 0.029 & 0.017 \\
RMSPE Benchmark & 11.46 & 11.61 & 11.7 \\
FIT Index & $1.30 \%$ & $0.25 \%$ & $0.14 \%$ \\
\hline
\end{tabular}

Notes: Table shows the fit indicators for three pre-treatment periods.Fit index shows values that suggest adequate adjustment for the three periods.

\footnotetext{
${ }^{10}$ Equation (9) in Appendix A determines optimal weights
} 


\subsection{Synthetic Control results}

Figure 3 shows the evolution of the log of mortgage loans in comparison to its synthetic counterfactual, from the second quarter of 2011 to the end of the fourth quarter of 2014. The difference between the two curves represents the effect of the regulatory change implemented in September 2013. As expected, mortgage loans relatively decrease between Brazil and synthetic Brazil in the quarter immediately after the LTV intervention. Conversely, in subsequent quarters mortgage loans increase increasing more in Brazil than in its synthetic counterpart.

Figure 3: Log mortgage loans balance: Brazil $\times$ Synthetic (in USD)

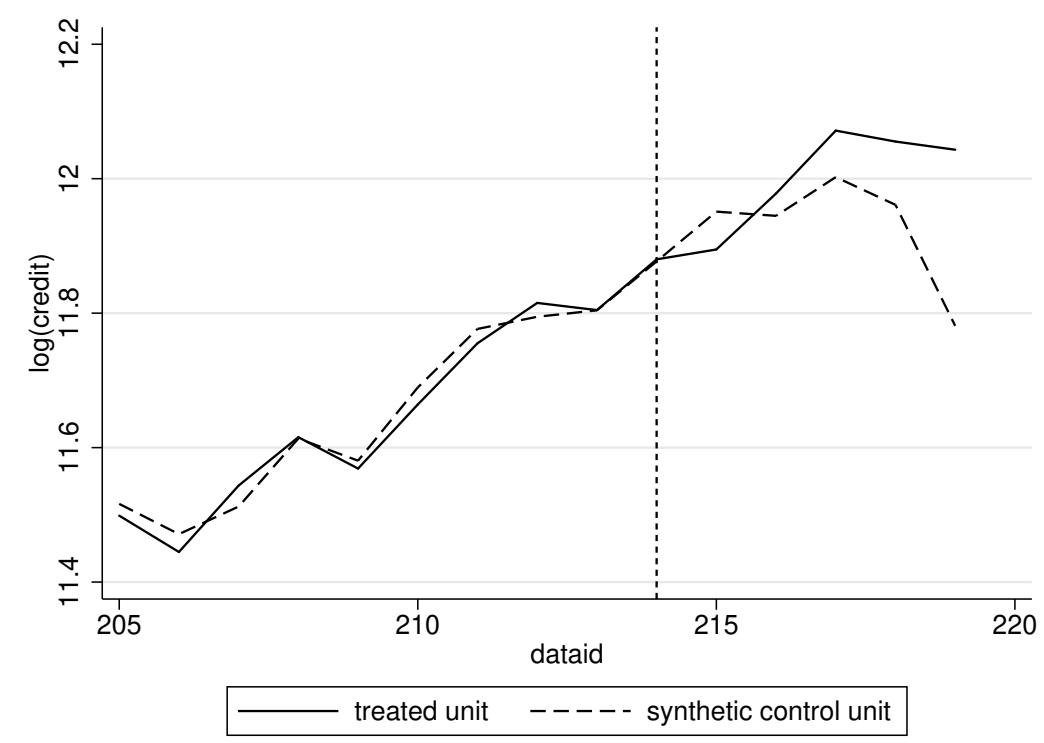

Note: See donor country weights in Table B.1 in Appendix B.

Table 4: Twelve month growth rate in log real estate credit after LTV (in USD)

\begin{tabular}{l|r|r|r|r|r}
\hline & $\Delta T 1$ & $\Delta T 2$ & $\Delta T 3$ & $\Delta T 4$ & $\Delta T 5$ \\
\hline Treated & 0.14 & 0.16 & 0.27 & 0.18 & 0.15 \\
Synthetic & 0.17 & 0.15 & 0.20 & 0.08 & -0.17 \\
\hline Estimated Treatment Effect & -0.03 & 0.01 & 0.07 & 0.09 & 0.32 \\
\hline
\end{tabular}

Notes: Table shows the twelve-month variation in the log mortgage loans for the treated and synthetic units- in percentage. Treatment effect is calculated based on the difference between variations for treated and synthetic units in five quarters after the adoption of the regulatory change.

Table 4 presents twelve-month growth rate in log mortgage loans for Brazil and its synthetic part. It is based on variations for treated and synthetic units (Figure 3) for five quarters after the adoption of the LTV. Results suggests the mortgage loans growth rate is higher for Brazil compared with its synthetic in second to fifth quarters after the intervention. 
We identified that the government, with Resolution 4,271 from 2013, raised the maximum acceptable mortgage loan at the same time as the LTV. Both measures have opposite effects, which makes the Resolution final effect ambiguous. This explains the lack of distinguishable effect on total mortgage loans using Synthetic Control. In conclusion, these estimates are lower bounds, but important to guide future investigation that will find better ways to estimate the causal effect of macroprudential policies such as LTV.

Analytical expressions for estimates confidence intervals do not exist. To infer on the results Abadie et al. (2007) suggest running a series of placebo regressions having each country in the donor pool as the treated unit. Figure 4 presents the results of such estimates. It is basically equal to Figure 3, but instead of the logarithm of credit as dependent variable, each line represents the difference between the logarithm of credit of a treated unit and its synthetic counterpart. The closer to zero that line, the better the adjustment of the model, and since models use pre-intervention characteristics to obtain the weights of each country, the models adjustments are naturally better in the pre-intervention period. If LTV intervention in Brazil was binding we would expect the difference to be the most negative if Brazil was the treated unit, bellow all other potential treated units. However, Figure 4 shows a difference similar to other potential treated units after LTV imposition in Brazil. Thus, the result in terms of credit growth is inconclusive.

Figure 4: Placebo Deviation from Synthetic Placebos (in USD)

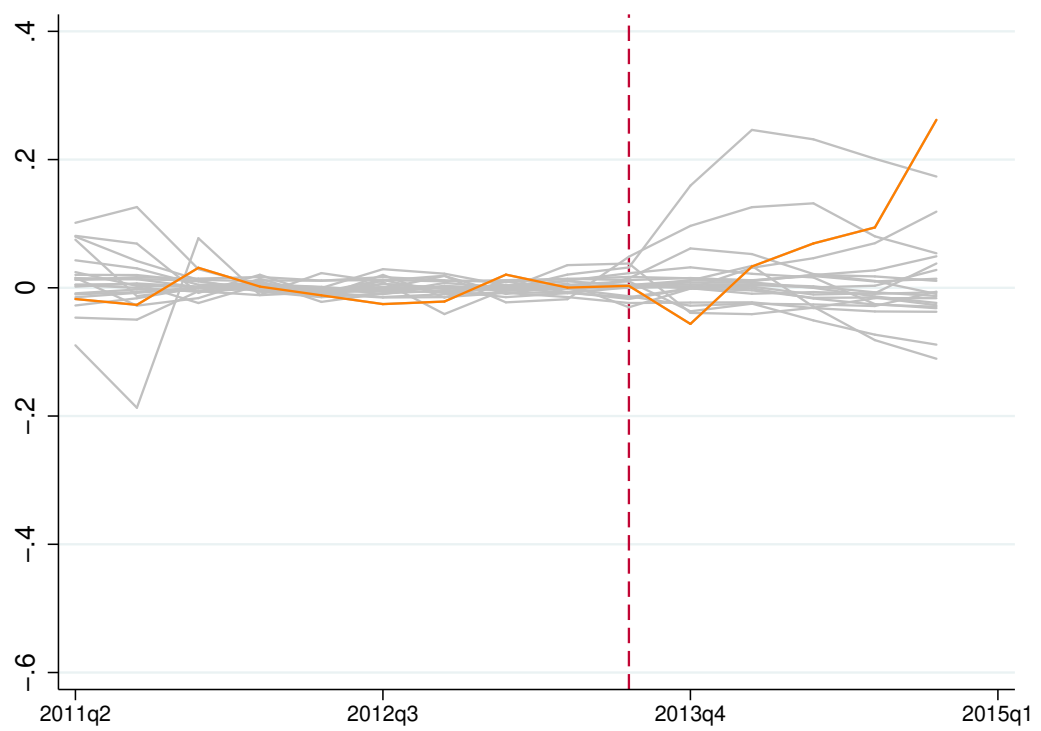

Notes: Each line represents the difference between the logarithm of credit of a treated unit and its synthetic counterpart. The closer to zero that line, the better the adjustment of the model, and since models use pre-intervention characteristics to obtain the weights of each country, the models adjustments are naturally better in the pre-intervention period. If LTV intervention in Brazil was binding we would expect the difference to be the most negative if Brazil was the treated unit, bellow all other potential treated units. However, Figure 4 shows a difference similar to other potential treated units after LTV imposition in Brazil. Thus, the result in terms of credit growth is inconclusive. 
Abadie et al. (2014) suggest computing the ratio between post and preintervention RMSPE for each unit to assess how effective the strength of the treatment is. Although we cannot make traditional statistical inference with this estimator, the authors suggest that counting the number of units that present higher ratios than the one that was actually treated may be effective to determine the intervention effect. Ideally, $0 \%$ of the observations should present higher ratios than the treated unit. Figure 5 summarizes the ratio between RMSPE post and pre-intervention. Countries in Figure 5 are displaced in alphabetical order in the x-axis, whereas the ratio of post RMSPE to pre-RMSPE is displaced in the y-axis. Since Brazil is the only country in our database that set LTV limits in the mortgage market during the period, we expected it to present the highest ratio. However, 6 out of 24 donors present the post/pre-treatment relation higher than Brazil's, thus indicating that a random country would have a $25 \%$ probability of presenting post/pre-treatment relation as high as Brazil's-an insufficient outcome to infer treatment significance.

Figure 5: Post/Pre-RMSPE (root mean square prediction error) relation for each placebo unit

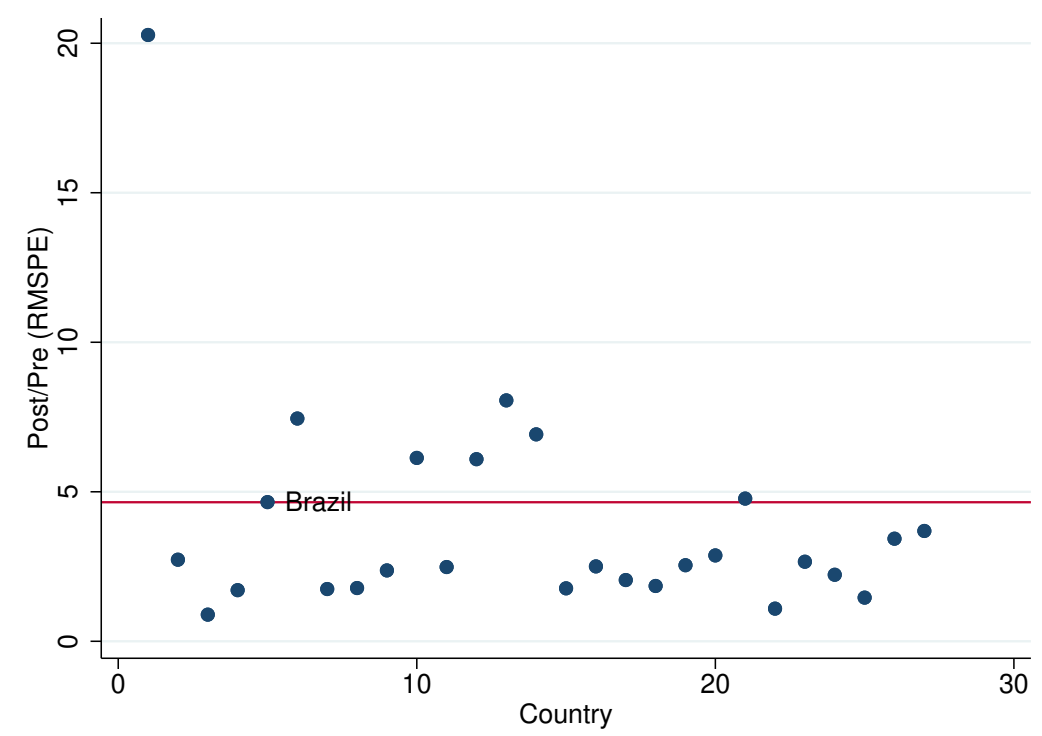

Notes: Figure 5 summarizes the ratio between RMSPE post and pre-intervention. Countries in Figure 5 are displaced in alphabetical order in the x-axis, whereas the ratio of post RMSPE to pre-RMSPE is displaced in the y-axis. Since Brazil is the only country in our database that set LTV limits in the mortgage market during the period, we expected it to present the highest ratio. However, 6 out of 24 donors present the post/pre-treatment relation higher than Brazil's, thus indicating that a random country would have a $25 \%$ probability of presenting post/pre-treatment relation as high Brazil's an insufficient outcome to infer treatment significance.

\section{Mortgage Portfolio Quality after LTV}

Results in Section 3.1 suggest the difference in total real estate credit between Brazil and its synthetic part is equal to zero. That result would follow if the 
LTV limit was not binding. In fact, if the LTV limit was not binding the credit portfolio quality would not improve. This section conducts a test of LTV effect on a measure of the quality of mortgage portfolio.

Table 5: Evolution of the Credit Portfolio Composition (billion reais)

\begin{tabular}{l|c|c|c|c}
\hline & $\begin{array}{c}\text { Private } \\
\text { - HFS }\end{array}$ & $\begin{array}{c}\text { Public } \\
\text { - HFS }\end{array}$ & $\begin{array}{c}\text { Private } \\
\text { - RSFS }\end{array}$ & $\begin{array}{c}\text { Public } \\
\text { - RSFS }\end{array}$ \\
\hline mar/13 & 30.47 & 284.62 & 31.75 & 0.42 \\
jun/13 & 30.91 & 305.57 & 35.26 & 2.94 \\
sep/13 & 32.39 & 325.77 & 38.10 & 3.60 \\
dec/13 & 34.18 & 344.24 & 35.06 & 3.74 \\
mar/14 & 35.69 & 330.11 & 36.46 & 29.72 \\
jun/14 & 37.26 & 343.34 & 38.27 & 32.71 \\
\hline
\end{tabular}

Notes: Table shows total mortgage portfolio based on the ownership status of the institution, public or private and on the type of loans regulated/subsidized (SFH) or non-regulated/market-rate (SFI). The volume of the portfolio is expressed in billions of reais. Prices are constant to values of June 2017.

Table 5 public banks are important in the mortgage market. SFH credit given by public banks amounted to over 82\% of total loans in March 2013. That decreased to $76 \%$ in June 2014. SFH loans by public banks increased from 284.62 billion reais in March 2013 to 344.24 billion reais in December same year. In the following quarters, SFH loans remained relatively stable. SFI loans by public banks, on the other hand, increased significantly, from 0.42 billion in March 2013 to 32.71 billion in June 2014 .

Central Bank of Brazil uses letters to classify the operations according to Resolution 2,682 from of $1999^{11}$. Standard risk operations, i.e., the ones with delay of up to 60 days, are classified in descending order of risk as AA, A, B and $\mathrm{C}$. Credit is considered progressively more problematic from categories $\mathrm{D}$ to $\mathrm{H}$. Variable $Y_{i t}$ denotes the proportion of problematic credit on total portfolio.

$$
Y=\frac{(\text { Portfolios } D+E+F+G+H)}{(\text { Portfolios } A A+A+B+C+D+E+F+G+H)} \times 100
$$

We used data on mortgage loans registered in the Central Bank of Brazil Credit Information System Central Bank of Brazil. According to the database, all loans by financial institutions at values higher than a thousand reais are recorded and classified based on their risk level.

Figure 6 describes the proportion of non-performing mortgage loans during the period immediately before and after the LTV imposition in September 2013. It is based on the quality index in equation (5). The figure shows that the proportion of credit considered problematic is very low, around $5 \%$ for SFH - regulated/subsidized - and $2 \%$ for SFI - non-regulated/market-rate. Besides, right after LTV enactment, the quality indicator among SFI credit deteriorated slightly more.

Figure 7 shows an exploratory exercise with the proportion of problematic mortgage loans on total portfolio (classified D and higher, that is, with

\footnotetext{
${ }^{11}$ See also Relatório de estabilidade financeira by Brazilian Central Bank (2017)
} 
Figure 6: Evolution of the portfolio quality between 2013 and 2015 by type of credit $(\mathrm{SFH} \times \mathrm{SFI})$

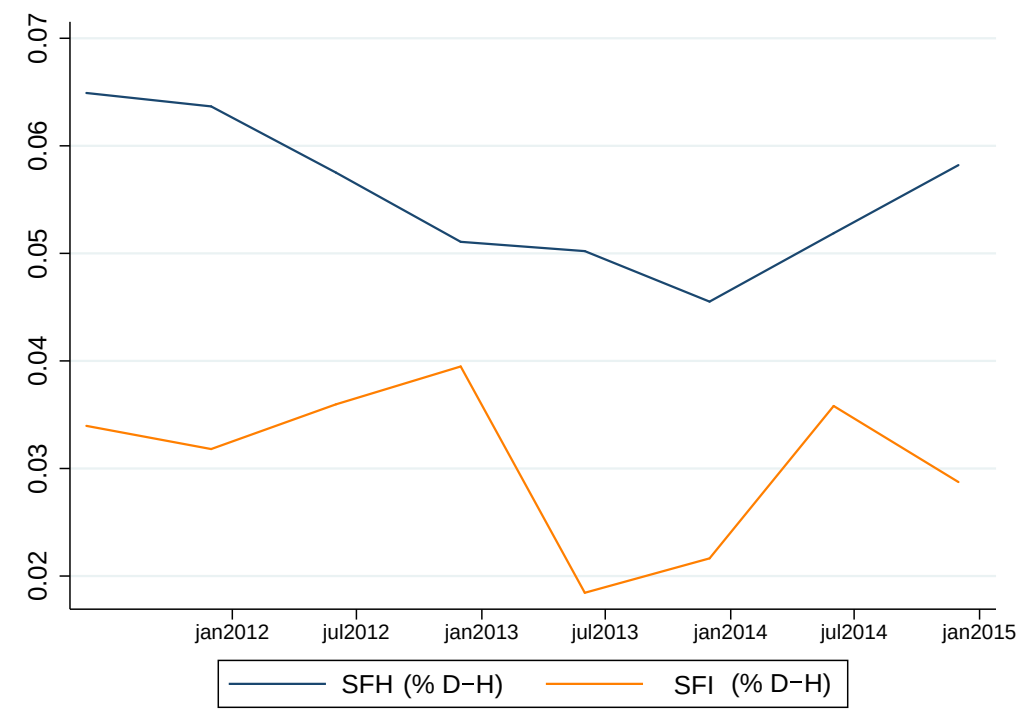

The figure describes the proportion of non-performing mortgage loans during the period immediately before and after the LTV imposition in September 2013.

Non-performing mortgage loans are defined based on the quality index in Equation

(5): $Y_{i t}=\frac{\text { Portfolios } D+E+F+G+H}{\text { Portfolios } A A+A+B+C+D+E+F+G+H} \times 100$

Source: Credit Information System Central Bank of Brazil.

payments delayed for more than 90 days) before and after LTV using interrupted time series ${ }^{12}$. This is a type of regression discontinuity, in which time is the treatment assignment variable (forcing variable). For such a methodology to work properly we need high frequency data and the effects after LTV enactment to be instantaneous. Nevertheless, neither condition is met in this exercise. We have few degrees of freedom, and effects of LTV may take a long time to be noticed. Thus, Figure 7 should work only as an auxiliary exercise.

We could also have added control variables that may confound the results in Figure 7, but few macroeconomic variables present with quarterly information, and even using some of these variables as controls, we still have few degrees of freedom. Still, this figure offers good insights. Adjusting a flexible polynomial on both sides of the intervention threshold, we find an immediate decrease in problematic loans of 0.37 percentage points (pp.). The decrease remains throughout the period under analysis, with a total reduction of almost 1 pp. after 15 months. Such a reduction is not negligible, once we are measuring the quality of the entire portfolio a stock variable and that problematic loans for SFH and SFI amount to less than 5\% of the total.

Difference-in-differences (DID) is another strategy used to evaluate the effect of LTV on credit portfolio quality. We used data on SFH and SFI mortgage loans at the municipal level. Municipalities with few operations were excluded from the database so not to compromise their confidentiality. Municipalities with unbalanced SFH and SFI portfolios were also excluded. The

\footnotetext{
${ }^{12}$ This design is often applied to evaluate regulatory changes in financial markets, and health policies with immediate effects (Abe 2016).
} 
Figure 7: Adjusting an interrupted time series (ITS) to explain total mortgage portfolio quality before and after LTV enactment

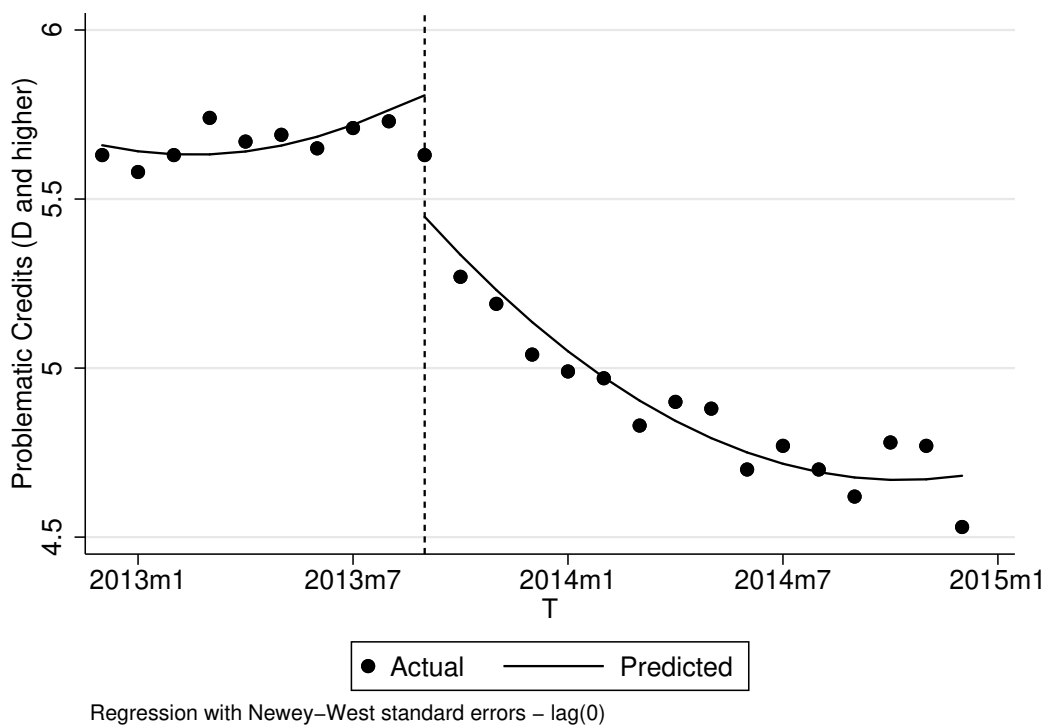

Notes:This figure shows a parametric exercise that allows us to figure possible discontinuous effects produced by the LTV ceiling. We adjust a flexible polynomial with Newey-West standard errors on both sides of the intervention threshold: $Y_{t}=\underset{(0.037)}{5.66}-\underset{(0.015)}{0.022} t_{t}-\underset{(0.077)}{0.368} X_{t}-\underset{(0.044)}{0.174} t_{t} X_{t}+\underset{(0.002)}{0.004} t_{t}^{2}$, where $X_{t}$ is a dummy indicating the periods before (equal to 0 ) and after LTV enactment; $t_{t}$ is a time trend and $Y_{t}$ the proportion of loans classified as D or higher on total mortgage loans. The figure shows an immediate decrease of 0.37 percentage points (pp.) in problematic credit. The decrease remains throughout the period under analysis, with a total reduction of almost 1 pp. after 15 months. Such a reduction is not negligible, once we are measuring the quality of the entire portfolio a stock variable and that problematic credits for SFH and SFI amount to less than $5 \%$ of total credit.

Source: Financial Stability Reports (Banco Central do Brasil, 2017).

estimation strategy consists in exploring a group affected by the regulatory change (SFH) - treated group - and another group not subjected to that change (SFI) - control group. DID design rely on the hypothesis treated and control groups would follow parallel tendencies in the absence of treatment. Treatment effect is given by the difference between treatment and control groups of the variations before and after the intervention. DID model can be expressed by:

$$
Y_{i t}=\alpha+\beta T_{t}+\gamma D_{i}+\theta T_{t} D_{i}+\varepsilon_{i t}
$$

$Y_{i t}$ denotes the proportion of mortgage loans classified as $\mathrm{D}$ or higher on total loans; $T_{t}$ is a dummy denoting time (equal to 0 before and to 1 after LTV enactment); $D_{i}$ denotes eligibility to treatment, equal to 1 for total SFH portfolio and 0 for total SFI portfolio in each municipality; and interaction $\left(T_{t} D_{i}\right)$ shows effective treatment situation. The treatment effect is given by $\theta$. 


\subsection{DID results}

Estimates with data from loans of SFH and SFI by municipalities are presented in Table 6. The estimation strategy consists in exploring a group affected by the regulatory change (SFH) treated group and another group not subjected to that change (SFI) control group. Figure 6 also describes the dataset. We do not need to control for macroeconomic confounding factors in this case, because they are common to all municipalities, and are thus captured by the time dummy. Table 6 summarizes treatment effect for 6 and 12 months after treatment. The DID estimator shows significant result after 6 months. It shows that after treatment, mortgage portfolio quality of SFH loans improved 0.66 percentage points in relation to SFI loans. The magnitude of the treatment effect cannot be neglected, since the quality of new loans affected by the treatment is diluted in total portfolio. The DID treatment effect on the quality of the portfolio corroborates that described by Araujo et al. (2017).

Table 6: Difference-in-differences results on mortgage portfolio quality

\begin{tabular}{l|c|c}
\hline & After 6 months & After 12 months \\
\hline$T_{t}$ & $0.2568^{* *}$ & -0.0492 \\
& $(0.1061)$ & $(0.1279)$ \\
$D_{i}$ & $4.0158^{* * *}$ & $3.7946^{* * *}$ \\
& $(0.1013)$ & $(0.1357)$ \\
$D_{i} T_{t}$ & $-0.6594^{* * *}$ & 0.2260 \\
& $(0.1134)$ & $(0.1457)$ \\
Cons & $0.4961^{* * *}$ & $1.1927^{* * *}$ \\
& $(0.0891)$ & $(0.1230)$ \\
\hline R-squared & 0.37 & 0.33 \\
N & 3756.00 & 3324.00 \\
\hline Notes: ${ }^{*}: p<0.10 .^{* *}: p<0.05 .^{* * *}: p<0.01$.
\end{tabular}

On the other hand, results show no significance after 12 months. That may be the consequence of a higher deterioration in the non-regulated portfolio. Borrowers may have migrated to non-regulated SFI loans with higher interest rates. Cizel et al. (2016) investigate the effect of replacing the regulated sector (bank credit) with the non-regulated one (non-bank credit) in an empirical study based on data from 40 countries. According to their study, the regulated mortgage market decreased $10 \%$ in the two years after the implementation of macroprudential policies; whereas the non-regulated segment showed increased growth rate of $5 \%$. Total mortgage loans declined $8 \%$, thus indicating the growth in the non-regulated sector did not compensate for the decline in the regulated sector. The study concludes an effect of substitution from the regulated sector with the non-regulated one, indicating worsening in the risk classification of the non-regulated sector.

Table 7 shows the robustness test of parallel trends between treatment and control groups in the pre-treatment period. Results show no significant differences in pre-treatment trends, which indicates the results at 6 months after LTV intervention is not the result of a pre-existing trend.

Figure 8 shows parallel treatment and control trends of mortgage portfolio quality in the period of 6 months before the LTV enactment. Such a result 
Table 7: Difference-in-differences pre-treatment test of parallel trends

\begin{tabular}{|c|c|}
\hline & (1) \\
\hline$T_{t}$ & $\begin{array}{c}-0.6966^{* * *} \\
(0.1275)\end{array}$ \\
\hline$D_{i}$ & $\begin{array}{l}3.7946^{* * *} \\
(0.1357)\end{array}$ \\
\hline$D_{i} T_{t}$ & $\begin{array}{c}0.2212 \\
(0.1360)\end{array}$ \\
\hline Cons & $\begin{array}{l}1.1927^{* * *} \\
(0.1230)\end{array}$ \\
\hline $\begin{array}{l}\text { R-squared } \\
\mathrm{N}\end{array}$ & $\begin{array}{c}0.33 \\
3540.00\end{array}$ \\
\hline
\end{tabular}

suggests the statistical significance of the effect of the LTV enactment on mortgage portfolio quality was not due to previous trend differences.

Figure 8: Estimates of the mortgage portfolio quality before the LTV enactment

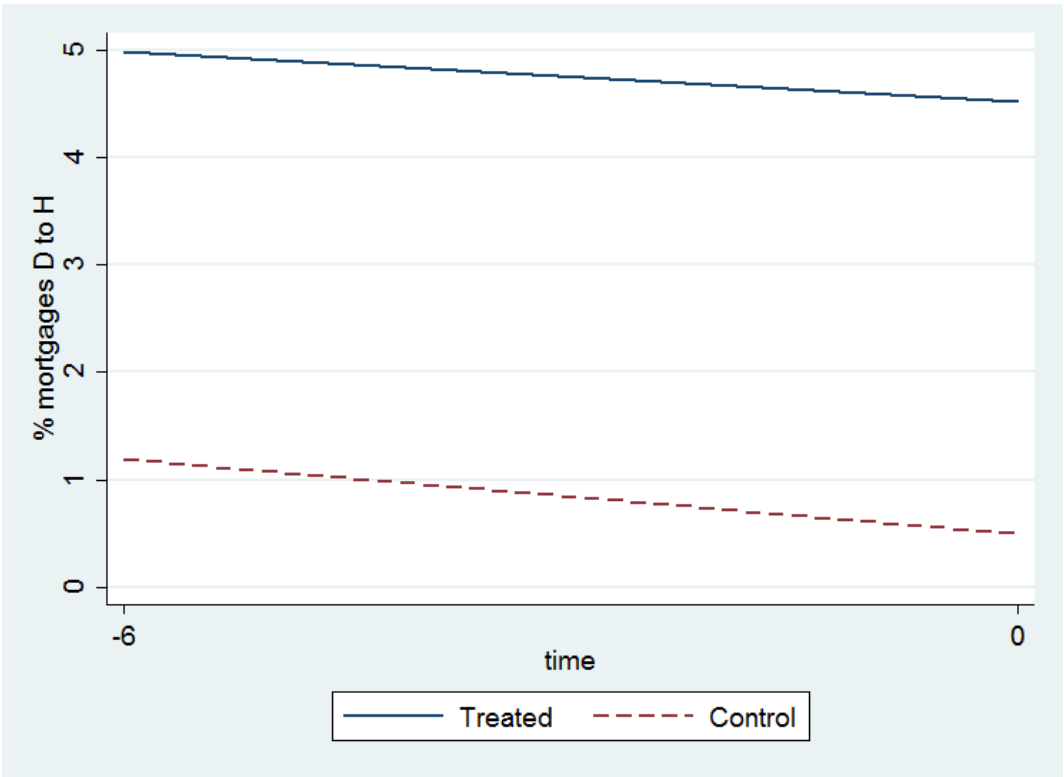

Notes: This figure shows parallel trends of treatment and control groups in the period of 6 months before the LTV enactment. Treatment group represents SFH loans, affected by the regulation, in each municipality. Control group represents non-regulated SFI loans in each municipality.

Figure 9 shows the proportion of non-performing mortgages for a long period (from January 2004 to September 2013) before LTV enactment. Although the quality levels of the SFH and SFI mortgage portfolios are different, the dynamics in the pre-treatment period is similar between the two groups. That suggests no pre-existent trend differences, and the results in Table 6 may be causal. 
Figure 9: The evolution of mortgage portfolio quality in the preintervention period (from January 2004 to September 2013)

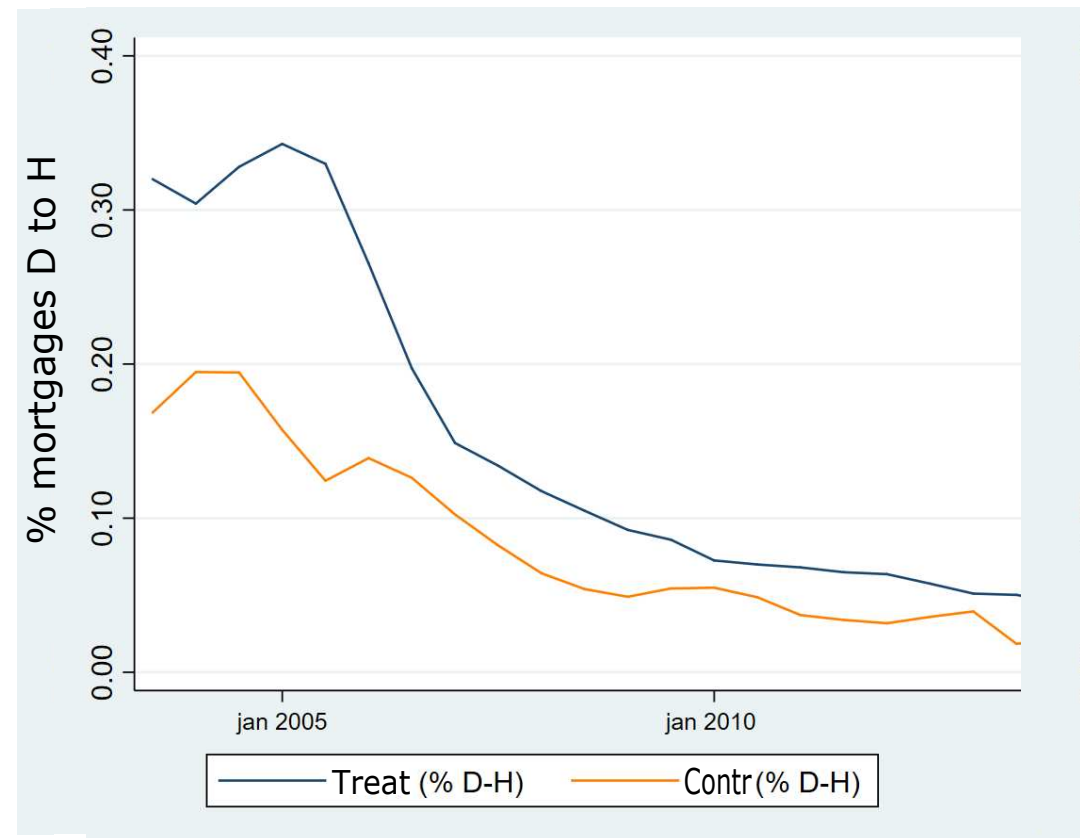

The figure shows the evolution of mortgage portfolio quality in the pre-intervention period, from January 2004 to September 2013.

\section{Final Remarks}

This study evaluates the effect of the regulatory change that implemented an LTV ceiling on mortgage loans growth dynamics and on the quality of the mortgage portfolio. We explore aggregate datasets because Microdata on credit operation are confidential. Nonetheless, this study shows it is feasible to work with impact evaluation methodologies with aggregated or more disaggregated data.

We begin focusing on the impact of the regulatory change on total mortgage loans using Synthetic Control, which avoids heterogeneous LTV interventions observed in country level panels. Results show the housing credit growth dynamics was not affected by the LTV enactment in Brazil. Although Lim et al. (2011) and Cizel et al. (2016) find decreasing mortgage loans after LTV ceiling implementations, this effect is not observed in Brazil. Competing hypothesis can explain this result. First, Brazilian LTV was not binding. Second, LTV may be binding, but LTV reduced the perceive risk of financial institution, which increased credit supply in response, canceling out the credit reduction by LTV enactment. Third, increases in the real estate maximum financing value were adopted simultaneously with the LTV ceiling, also canceling out effects.

After that, we check the aggregated behavior of the mortgage portfolio quality before and after the LTV introduction using interrupted time series, observing a significant change in total quality of the portfolio regulated (SFH) and non-regulated (SFI). This analysis allows us to observe general balance effects of regulated and non-regulated mortgage portfolio quality. 
Results obtained through DID corroborated the study by Cizel et al. (2016) and Araujo et al. (2017), since they show statistically significant effects of the regulation on the quality of the regulated group (SFH) in comparison to the non-regulated one (SFI) in the short run (6 months after treatment). In the long run, the effect vanishes, which may be the result of substitution effect between regulated and non-regulated loans, which influences DID estimates but not ITS, which continues to show LTV significant effects after 12 months.

\section{References}

Abadie, A., Diamond, A. \& Hainmueller, J. (2007), 'Synthetic control methods for comparative case studies: estimating the effect of California's tobacco control program, Working Paper, National Bureau of Economic Research. Available from: https://www.nber.org/papers/w12831.pdf. Access in: dez. 13 2019', (12831).

Abadie, A., Diamond, A. \& Hainmueller, J. (2010), 'Synthetic control methods for comparative case studies: Estimating the effect of california's tobacco control program', Journal of the American Statistical Association 105(490), 493-505.

Abadie, A., Diamond, A. \& Hainmueller, J. (2014), 'Comparative politics and the synthetic control method', American Journal of Political Science 59(2), 495510 .

Abadie, A. \& Gardeazabal, J. (2003), 'The economic costs of conflict: a case study of the basque country', The American Economic Review 93(1), 113-132.

Abe, T. M. O. (2016), Internação e mortalidade por doença cardiovascular e cerebrovascular no período anterior e posterior à lei antitabaco na cidade de São Paulo, tese de Doutorado, Universidade de São Paulo, São Paulo.

Adhikari, B. \& Alm, J. (2016), 'Evaluating the economic effects of flat tax reforms using synthetic control methods', Southern Economic Journal 83(2), 437-463.

Afanasieff, T. S., Carvalho, F. L. C. A., Castro, E. C., Coelho, R. L. P. \& Gregório, J. (2015), 'Implementing Loan-to-Value Ratios: the case of auto loans in Brazil (2010-2011)', Working Paper . Banco Central do Brasil. Available from: https://www.bcb.gov.br/pec/wps/ingl/wps380.pdf. Access in: dez. 132019.

Araujo, D. K. G., Barroso, J. B. R. B. \& Gonzalez, R. B. (2017), 'Loanto-value policy and housing loans: effects on constrained borrowers', Working Paper . Bank for International Settlements. Available from: <https://www.bis.org/publ/work673.pdf>. Access in: dez. 162019.

Bai, C., Li, Q. \& Ouyang, M. (2014), 'Property taxes and home prices: a tale of two cities', Journal of Econometrics 180(1), 1 - 15.

URL: $h t t p: / / w w w . s c i e n c e d i r e c t . c o m / s c i e n c e / a r t i c l e / p i i / S 0304407613002674$

Cerutti, E. M., Claessens, S. \& Laeven, L. (2015), 'The use and effectiveness of macroprudential policies: new evidence. working paper', International Monetary Fund . 
Cizel, J., Frost, J., Houben, A. \& Wierts, P. (2016), 'Effective macroprudential policy: cross-sector substitution from price and quantity measures', Working Papers, International Monetary Fund 16/94.

Claessens, S., Ghosh, S. R. \& Mihet, R. (2013), 'Macro-prudential policies to mitigate financial system vulnerabilities', Journal of International Money and Finance 39, $153-185$.

Crowe, C. W., Dell'Ariccia, G. \& Igan, D. O. (2011), 'How to deal with real estate booms', Working Paper, International Monetary Fund . Available from: <https://www.imf.org/external/pubs/ft/wp/2011/wp1191.pdf>. Access in: 16 dez. 2019.

Gete, P. \& Reher, M. (2016), 'Two extensive margins of credit and loan to value policies', Journal of Money, Credit and Banking 48(7).

Kuttner, K. N. \& Shim, I. (2016), 'Can non-interest rate policies stabilize housing markets? evidence from a panel of 57 economies', Journal of Financial Stability 26, $31-44$.

URL: http://www.sciencedirect.com/science/article/pii/S1572308916300705

Li, L. \& Yavas, A. (2017), 'Land share, mortgage default, and loan-tovalue ratio as a macro-prudential policy tool', Working Paper. Available from: <https://papers.ssrn.com/sol3/papers.cfm?abstract_id=2980558>. Access in: dez. 162019.

Lim, C., Columba, F., Costa, A., Kongsamut, P., Otani, A., Saiyid, M. \& Wu, X. (2011), 'Macroprudential policy: what instruments and how to use them? lessons from country experiences', Working Papers, International Monetary Fund . Available from: <https://www.imf.org/external/pubs/ft/wp/2011/wp11238.pdf>. Access in: 16 dez. 2019.

Martins, B., Lundberg, E. \& Takeda, T. (2011), 'Housing finance in Brazil: institutional improvements and recent developments', Working Paper .

URL: $h t t p: / / d x$.doi.org/10.2139/ssrn.1946143

Morgan, P. J., Regis, P. J. \& Salike, N. (2018), 'LTV policy as a macroprudential tool and its effects on residential mortgage loans', Journal of Financial Intermediation 37, 89 - 103.

URL: $h$ ttp://dx.doi.org/10.2139/ssrn.1946143

Otto, S. (2015), 'Real estate policy in Brazil and some comparisons with the United States', Stanford, Centre for International Development Working Paper . Working Paper, Stanford University. Available from: <https://stanford.io/2R2hZYD>. Access in: 16 dez. 2019.

Regional Economic Outlook Analytical Notes (2012), 'Keeping an Eye on Housing Markets in Latin America'. Working Paper. Available from: https://webcache.googleusercontent.com/search?q=cache:Ry3VQHc1JjkJ:ht tps://www.imf.org/media/Websites/IMF/imported-flagship-

issues/external/pubs/ft/reo/2012/whd/eng/pdf/_wreo013013pdf.ashx+\&c $\mathrm{d}=1 \& \mathrm{hl}=\mathrm{pt}-\mathrm{BR} \& \mathrm{ct}=\mathrm{clnk} \& \mathrm{gl}=\mathrm{br}$. Access in: $16 \mathrm{dez} .2019$. 
Silva, L. A. P., Sales, A. S. \& Gaglianone, W. P. (2012), 'Financial stability in Brazil', $289 . \quad$ Available from: <https://ideas.repec.org/p/bcb/wpaper/289.html>. Access in: 16/12/2019.

Wong, E., Fong, T., Li, K.-f. \& Choi, H. (2011), 'Loan-to-value ratio as a macroprudential tool: Hong Kong's experience and cross-country evidence'. Available from: <https://ideas.repec.org/p/hkg/wpaper/1101.html $>$. Access in: 16 dez. 2019. 


\section{Appendix A}

Originally developed by Abadie \& Gardeazabal (2003) and Abadie et al. (2010) the Synthetic Control (SC) methodology has been widely adopted in comparative evaluation studies for unique interventions performed at aggregate level. Case studies - such as the LTV enactment - try to predict the evolution of an aggregate outcome variable for the treated unit by comparing it to an average of units - called Synthetic Control- that resembles the treated unit as much as possible.

The standard model by Abadie et al. (2007) presents a single treated unit $i$, which is exposed to treatment after period $T_{0}$, i.e., during periods $T_{0}+1, T_{0}+$ $2, \ldots, T$, and $J$ untreated units that are potential donors for the synthetic control. Taking $Y_{i t}$ as the dependent variable, the estimated effect is the difference between the two potential outcomes expected for post-treatment periods:

$$
\alpha_{1 t}=Y_{i t}^{I}-Y_{i t}^{N}, \quad t>T_{0}
$$

where $Y_{i t}^{I}$ is the potential outcome if unit $i$ was exposed to treatment and $Y_{i t}^{N}$ is the potential outcome of unit $i$ in period $t$ in the absence of intervention. Synthetic Control consists in estimating $Y_{i t}^{N}$ as a linear combination of the outcomes of untreated units similar to $i$.

$$
\hat{\alpha}_{1 t}=Y_{i t}^{I}-\sum w_{j}^{*} Y_{j t}^{J}{ }_{j=1}, \quad t>T_{0}, \quad i \neq j
$$

The weights $w_{j}^{*}$ are set to minimize the differences between pre-intervention characteristics of treatment and control units. $X_{i}$ denotes a vector of covariates and linear combinations of pre-intervention outcomes. Vector $\left(W^{*}, V^{*}\right)$ solves:

$$
\begin{array}{ll}
\min _{V, W} & X_{1}-X_{0} W=\sqrt{\left(X_{1}-X_{0} W\right)^{\prime} V\left(X_{1}-X_{0} W\right)} \\
& \text { s.t. } \\
& w_{j}^{*} \geq 0 \\
& \sum_{j=1}^{J} w_{j}^{*}=1 \\
& j=1, \ldots, J \\
i \neq j &
\end{array}
$$

where $X_{0}$ contains covariates of units in the donor group; $X_{1}$ is characteristics of the treated unit; $V$ is a diagonal matrix with non-negative components that assign weights to the most important covariates in terms of prediction accuracy. After finding the first choice $V^{*}$, it is possible to choose $W^{*}$ to minimize the mean square prediction errors (MSPE). With optimal $W^{*}, \sum w_{j}^{*} Y_{j t}^{J}{ }_{j=1}$ can be obtained before and after intervention and then compared with the outcome. Placebo tests with each observation are conducted to infer. 


\section{Appendix B}

Table B.1: Composition of the Synthetic Control (only countries with positive weights)

\begin{tabular}{l|c}
\hline Country & Unit Weight \\
\hline Australia & 0.073 \\
France & 0.165 \\
India & 0.123 \\
Peru & 0.006 \\
Russia & 0.634 \\
\hline
\end{tabular}

